\title{
Incidence and Risk Factors for Suicide Attempts in Patients Diagnosed with Major Depressive Disorder
}

This article was published in the following Dove Press journal: Psychology Research and Behavior Management

\author{
Angélica Gonçalves Peter (1) ${ }^{1,2}$ \\ Mariane Lopez Molina $\mathbb{D}^{3}$ \\ Taiane de Azevedo Cardoso 1,4 \\ Thaíse Campos Mondin ${ }^{5}$ \\ Ricardo Azevedo da Silva (DD ${ }^{1}$ \\ Karen Jansen' \\ Marcelo Machado Dornellas \\ de Barros' \\ Érico Nobre dos Santos $(\mathbb{D})^{\prime}$ \\ Kyara Rodrigues de Aguiar (D) \\ Luciano Dias de Mattos \\ Souza $\left.{ }^{1}\right)^{\prime}$
}

'Postgraduate Program in Health and Behavior, Catholic University of Pelotas (UCPel), Pelotas, Brazil; ${ }^{2}$ Educational Development Center, Federal University of Pampa, Jaguarão, Brazil; ${ }^{3}$ Psychology Department, Anhanguera Educational College of Rio Grande, Rio Grande, Brazil; ${ }^{4}$ Department of Psychiatry and Behavioural Neurosciences, McMaster University, Hamilton, Canada; ${ }^{5}$ Department of Student Affairs, Federal University of Pelotas, Pelotas, Brazil
Correspondence: Luciano Dias de Mattos Souza

Programa de Pós-Graduação em Saúde e Comportamento, Universidade Católica de Pelotas (UCPel), Rua Gonçalves Chaves, 373, Sala 4I8 C, Pelotas RS 96015-560, Brazil

Email luciano.dms@gmail.com
Objective: This study seeks to investigate the cumulative incidence and risk factors of suicide attempts in an outpatient sample of adults diagnosed with major depressive disorder (MDD).

Materials and Methods: This is a longitudinal study with 377 patients aged between 18 and 60 years. Those were diagnosed with MDD with no history of suicide attempts when they sought care at the Mental Health Outpatient Clinic of the Catholic University of Pelotas and evaluated again 3 years after. Participants were evaluated with the Mini International Neuropsychiatric Interview (MINI Plus) and answered instruments of clinical investigation and a sociodemographic questionnaire.

Results: The cumulative incidence of suicide attempts in the sample was $10.1 \%$. Youths aged up to 29 years (OR 2.23; 95\% CI 1.13 to 4.64), with low schooling (OR 2.35; 95\% CI 1.15 to 4.80 ), who suffered intense physical abuse during childhood (OR 2.77; 95\% CI 1.31 to 5.84 ) and were at prior suicide risk (OR 3.39; $95 \%$ CI 1.56 to 7.37 ) were more likely to attempt suicide.

Conclusion: The findings of this study may help health professionals identify depressed patients at greater risk for a first suicide attempt, supporting clinical decision and therapeutic planning.

Keywords: depression, suicide, attempt, incidence, longitudinal studies

\section{Introduction}

Suicide is one of the leading causes of death in the world. According to the World Health Organization (WHO), close to 800 thousand people die due to suicide every year. ${ }^{1}$ Because of its high prevalence, suicide is considered a public health problem and its prevention is advocated as a global imperative. ${ }^{1}$ Suicide attempts (SA) are 10 to 20 times more frequent than deaths due to suicide. ${ }^{2}$ SAs are also the most important risk factor for later suicide. ${ }^{1}$ Mental disorders are strongly associated with suicide and other forms of suicidal behavior. ${ }^{2}$

Major Depressive Disorder (MDD) is commonly associated with suicide. ${ }^{3-5}$ It is a highly prevalent and debilitating mental disorder with high prevalence. ${ }^{6}$ A longitudinal study on individuals with MDD has found that comorbidity with personality disorders, anxiety and use of psychoactive substances are risk factors for SAs. ${ }^{7}$ However, findings of the predictors of SA are not consistent in the literature. ${ }^{8-10}$ To our knowledge, there is none publication addressing predictors of SA in MDD

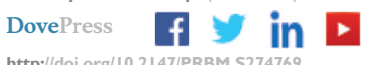


population this issue in Latin America although the relevance of sociocultural factors. ${ }^{1,2}$

Prior SA has been shown to be a strong predictor of suicide. ${ }^{7,9-12}$ Early-life exposure to trauma also appears to be an important risk factor. ${ }^{13}$ However, there is a paucity of longitudinal studies investigating the correlation between early trauma and SA in individuals diagnosed with MDD. Regarding other risk factors, the literature on the effects of sociodemographic factors such as age, marital status, education and income on suicide has shown diverse results, $7,9,12,14$ highlighting the need for new research on these variables as risk factors for suicide among MDD population.

In general, risk factors for SA in MDD populations are still not fully understood. ${ }^{15}$ Studies investigating the incidence of SAs throughout the life course and its predictors in depressed individuals are scarce $^{7}$ and new research determining causal relations is of importance. ${ }^{11}$ Better knowledge of SA predictors in MDD may help detecting individuals prone to suicidal behavior and support therapeutic interventions. As such, the aim of this study was to investigate the cumulative incidence and risk factors of SAs in an outpatient sample of MDD diagnosed adults. We hypothesized that intense childhood trauma experiences and higher social vulnerability would be identified as risk factors to suicide risk in MDD population.

\section{Materials and Methods}

\section{Sample and Procedures}

This is a longitudinal study carried out with 464 individuals diagnosed with MDD with no prior history of SA. These individuals were selected from participants that answered an open invitation for a mental health assessment carried out at the Mental Health Research and Extension Clinic of the Catholic University of Pelotas. The health assessment invitation was advertised at primary health units, centers of psychosocial support and other local healthcare services, schools and means of communication throughout the city of Pelotas (newspapers, websites, radio and television), seeking to recruit the largest possible number of participants.

A total of 966 individuals presented themselves for the mental health evaluation. Among those, 585 were diagnosed with MDD and 464 fulfilled the selection criteria for the study (age between 18 and 60 and no SA history). A baseline assessment of these individuals was carried out between July 2012 and June 2015. These participants were invited for a second assessment approximately 3 years later. Between January 2017 and February 2018, 377 participants out of the 464 invited were reassessed (18.8\% loss to followup). The present study was part of a larger clinical research. ${ }^{16}$ Unfortunately, only the association between previous suicide risk and incidence of suicide attempt presented a level of statistical power higher than $80 \%$. Other variables had presented a level of statistical power under $65 \%$ regarding the study outcome. Figure 1 presents the evaluation flowchart of the sample.

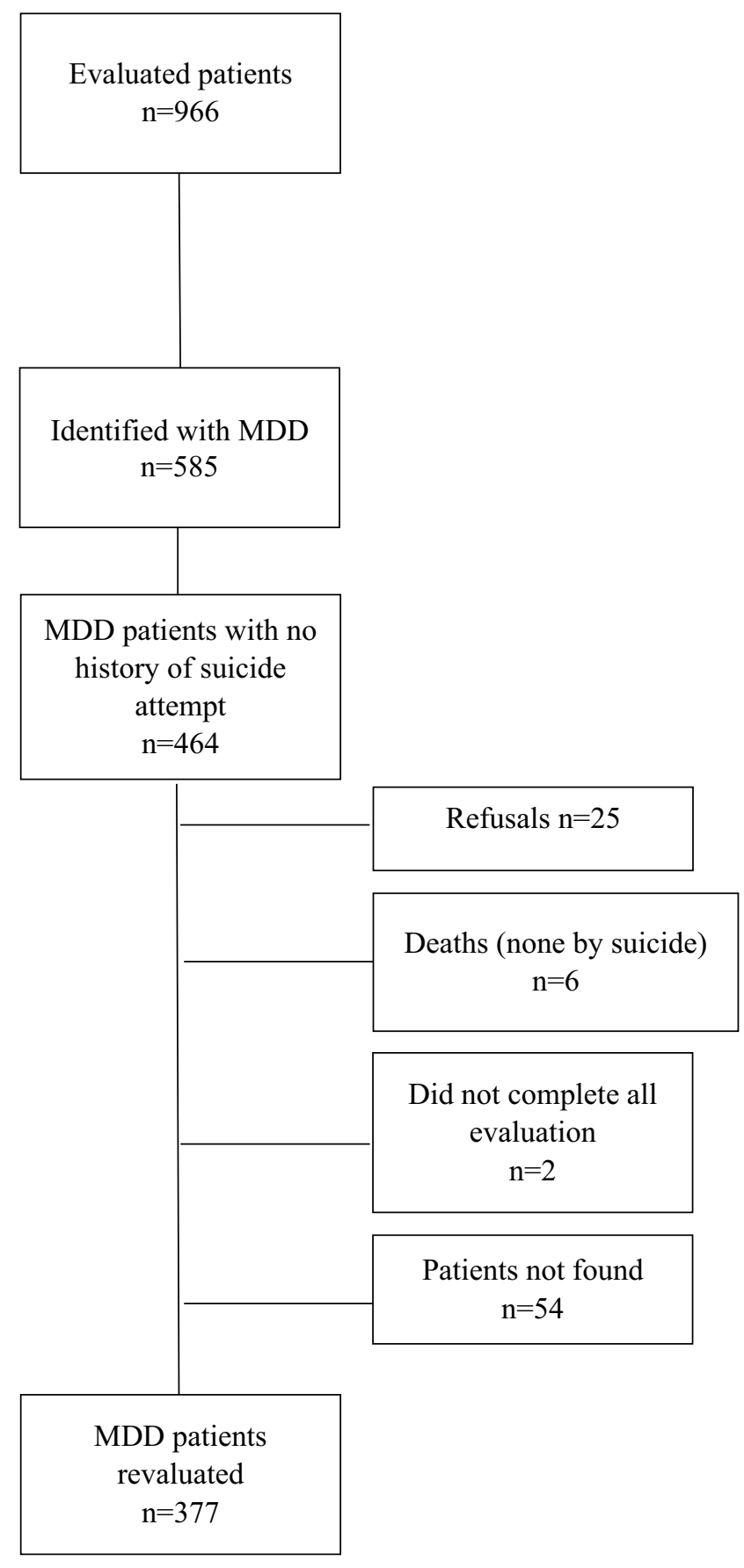

Figure I Evaluation flowchart of the sample. 
Psychologists of the Catholic University of Pelotas Mental Health and Behavior Postgraduate Program held the diagnostic interviews. Trained interviewers under regular supervision applied all other instruments.

\section{Instruments}

In order to select participants for the study, major depressive disorder and the history of SA were evaluated using the Mini International Neuropsychiatric Interview 5.0 (MINI). MINI is a short standardized diagnostic interview, compatible with DSM-IV and CID-10 criteria, used for mental health disorder evaluation throughout the lifetime. ${ }^{17}$ This instrument also allows the diagnostic of anxiety disorders (social phobia, specific phobia, generalized anxiety disorder and panic disorder), obsessive-compulsive disorder (OCD), post-traumatic stress disorder (PTSD) and suicide risk assessment. The suicide risk was measured by module $\mathrm{C}$ of MINI. This section is composed of five questions about the last month - 1) Did you think it would be better to be dead or wished you were dead? (yes = 1 point); 2) Did you want to hurt yourself? (yes $=2$ points); 3 ) Did you think about suicide? (yes $=6$ points); 4) Have you thought of a way to commit suicide? (yes $=10$ points); and 5) Did you attempt suicide? (yes $=10$ points) - and an additional question about the lifetime - 6) Have you ever made a suicide attempt? (yes $=4$ points). Any yes answer to the first five questions was an indicative of suicide risk. Any participant with yes at question 5 or 6 (history of suicide attempt) was excluded from the present data analysis.

We used the Alcohol Smoking and Substance Involvement Screening Test (ASSIST), a structured questionnaire, validated for the Brazilian population, ${ }^{18}$ for psychoactive drugs abuse/dependence evaluation. Early life trauma was evaluated using the Childhood Trauma Questionnaire (CTQ), a self-reporting instrument composed of 28 statements that investigates the early-life history of abuse and negligence comprising five dimensions: physical abuse, emotional abuse, sexual abuse, physical negligence and emotional negligence. ${ }^{19}$ For each CTQ dimension, as the same criteria of CTQ's Manual, the individuals in the top quintile of the score of the current sample were considered positive for intense trauma history.

The Multiaxial Clinical Milton Inventory III (MCMI-III) was applied to detect personality disorder indicatives. This instrument is composed of 28 scales for the evaluation of 14 personality patterns and 10 clinical syndromes. ${ }^{20} \mathrm{We}$ considered the top percentile $15 \%{ }^{21}$ of the initial sample evaluated $(n=966)$ for each personality disorders in the group who participated in the first interview (schizoid, schizotypal, paranoid, borderline, histrionic, narcissist, antisocial, dependent, obsessive-compulsive and avoidant).

Socio-demographic information was gathered using a questionnaire elaborated by the researcher team and the participants' economic status was estimated using an assetbased score proposed by the Brazilian Market Research Institutes Association. ${ }^{22}$ This instrument provides a score based on the total of material goods and the householder's schooling in which the higher the score better the socioeconomic condition. In this particular study to reduce the number of categorization in independent variables, we chose to dichotomize this information (Higher status/medium and lower status). ${ }^{22}$

The same instruments applied in the first evaluation were present at the second evolution, with exception to CTQ and MCMI-III. All the independent variables used in the analyses were from the baseline assessment (exposure variables). The outcome was defined as the follow-up interview through the affirmative answer to the question "Have you ever attempted suicide?" from the MINI module $\mathrm{C}$.

\section{Data Analysis}

Initially, we did a descriptive analysis of the sample characteristics and estimated the SA incidence. The crude association between the outcome and each independent variable was assessed using Pearson's chi-squared test. To adjust for confounding, multivariable logistic regression was used. Predictors with a p-value $<0.20$ in the crude analysis were included in the regression. ${ }^{23}$

The adjusted analysis was performed following a hierarchical conceptual model with three levels according to the associative analysis. The first level comprised sociodemographic variables (sex, age, education, occupation); the second level included variables related to the individual's life history (mother's SAs, intense physical abuse); and the third level included clinical and behavior-related variables (suicide risk, tobacco dependence/abuse, hypnotics dependence/abuse, schizoid personality disorder, borderline personality disorder). Associations showing a p-value $<0.05$ or effect measures with a confidence interval not including the unity were considered significant.

\section{Ethical Aspects}

This project was approved by the Catholic University of Pelotas ethical committee (process 1.879.902). The involvement of the study participants was voluntary and participants were informed of the right to withdraw anytime 
from the study; moreover, written informed consent was obtained from every participant before data collection. The participants were not paid or received any credit for participating in the survey. The data collection was undertaken confidentially and responses were kept private and anonymous. The study was conducted as per the Helsinki declaration. Individuals diagnosed with mental disorder and/or low risk of suicide were referred to municipal healthcare services for treatment. A participant's family member or trusted person was called to the study site in situations of moderate or severe suicide risk. This procedure was adopted to active the social support network of these participants and providing them with adequate guidance on referral to local psychiatric services.

\section{Results}

The reevaluated sample consisted mostly of female individuals (83.3\%), aged 30 years and over $(69.0 \%)$ and with 9 or more years of schooling $(72.4 \%)$. Most of the participants worked or studied $(64.2 \%)$, had partners $(57.6 \%)$, had children (66.8\%) and belonged to economic levels C, D or E - considered medium and lower (55.2\%) (Table 1). The reevaluated group was statistically different to the lost group from the baseline sample of 464 participants in two variables. A higher proportion of loss occurred in the male group (26.7\%) compared to female (16.9\%) and a higher proportion of participants that reported a history of SA of their mother (19.7\%) were lost compared with participants that did not report history of SA of their mother $(\mathrm{p}<0.050)$.

Regarding the variables related to life history, $6.9 \%$ of the participants reported that their mother had attempted suicide at least once, $25.2 \%$ had suffered intense physical negligence, $23.3 \%$ emotional negligence, $22.0 \%$ physical abuse, $19.9 \%$ emotional abuse and $20.4 \%$ sexual abuse (Table 2). Regarding psychiatric comorbidities, $61.5 \%$ of the interviewees presented any type of anxiety disorder, 23.6\% had OCD and 5.6\% had PTSD. The dependent personality disorder and avoidant personality disorder were the most frequent personality disorder (20.7\%).

Table I Socioeconomic Characteristics of Participants Diagnosed with MDD' and Their Association with Suicide Attempt Incidence

\begin{tabular}{|c|c|c|c|c|}
\hline Variables & $\begin{array}{l}\text { Population without Suicide Attempt at } \\
\text { Baseline and Reassessed } \mathbf{n}(\%) \\
377\end{array}$ & $\begin{array}{l}\text { Suicide Attempt } \\
\text { Incidence n (\%) }\end{array}$ & $\begin{array}{l}\text { Odds Ratios } \\
(95 \% \mathrm{CI})\end{array}$ & p - value** \\
\hline Sex & & & & 0.124 \\
\hline Female & $314(83.3)$ & $35(11.1)$ & 2.51 (0.75 to 8.43$)$ & \\
\hline Male & $63(16.7)$ & $3(4.8)$ & Reference & \\
\hline Age & & & & 0.054 \\
\hline Up to 29 years & II7 (3I.0) & $17(14.5)$ & 1.94 (0.98 to 3.82$)$ & \\
\hline 30 years or over & $260(69.0)$ & $21(8.1)$ & Reference & \\
\hline Schooling (years) & & & & 0.035 \\
\hline $0-8$ & $104(27.6)$ & $16(15.4)$ & 2.07 (1.04 to 4.13$)$ & \\
\hline $9+$ & $273(72.4)$ & $22(8.1)$ & Reference & \\
\hline Occupation* & & & & 0.111 \\
\hline None & 134 (35.5) & $18(13.4)$ & $1.72(0.88$ to 3.38$)$ & \\
\hline Works or studies & $242(64.2)$ & $20(8.3)$ & Reference & \\
\hline Economic Class* & & & & 0.736 \\
\hline Medium and lower status & $208(55.2)$ & $22(10.6)$ & I.I2 (0.57 to 2.22$)$ & \\
\hline Higher status & $168(44.6)$ & $16(9.5)$ & Reference & \\
\hline Marital Status & & & & 0.517 \\
\hline No partner & $160(42.4)$ & $18(11.3)$ & 1.25 (0.64 to 2.45$)$ & \\
\hline Has a partner & $217(57.6)$ & $20(9.2)$ & Reference & \\
\hline Has children & & & & 0.345 \\
\hline No & $125(33.2)$ & $10(8.0)$ & 0.70 (0.33 to 1.48$)$ & \\
\hline Yes & $252(66.8)$ & $28(I I . I)$ & Reference & \\
\hline
\end{tabular}

Notes: 'Major Depressive Disorder. *Variables with missing data. **Chi-square test. 
Table 2 Clinical History Characteristics of Participants Diagnosed with MDD' and Their Association with Suicide Attempt Incidence

\begin{tabular}{|c|c|c|c|c|}
\hline Variables & $\begin{array}{l}\text { n (\%) } \\
377\end{array}$ & $\begin{array}{l}\text { Suicide Attempt } \\
\text { Incidence } \\
\text { n (\%) }\end{array}$ & Odds Ratio (95\% Cl) & p - value* \\
\hline $\begin{array}{l}\text { Mother ever attempted suicide } \\
\text { No/Does not know } \\
\text { Yes }\end{array}$ & $\begin{array}{l}351(93.1) \\
26(6.9)\end{array}$ & $\begin{array}{l}33(9.4) \\
5(19.2)\end{array}$ & $\begin{array}{l}\text { Reference } \\
2.29(0.81 \text { to } 6.49)\end{array}$ & 0.108 \\
\hline $\begin{array}{l}\text { Father ever attempted suicide } \\
\text { No/Does not know } \\
\text { Yes }\end{array}$ & $\begin{array}{l}368(97.6) \\
9(2.4)\end{array}$ & $\begin{array}{l}36(9.8) \\
2(22.2)\end{array}$ & $\begin{array}{l}\text { Reference } \\
2.58(0.52 \text { to } 12.92)\end{array}$ & 0.221 \\
\hline $\begin{array}{l}\text { Another family member ever attempted suicide } \\
\text { No/Does not know } \\
\text { Yes }\end{array}$ & $\begin{array}{l}348(92.3) \\
29(7.7)\end{array}$ & $\begin{array}{l}35(10.1) \\
3(10.3)\end{array}$ & $\begin{array}{l}\text { Reference } \\
1.03(0.30 \text { to } 3.58)\end{array}$ & 0.961 \\
\hline $\begin{array}{l}\text { Intense Physical negligence } \\
\text { No } \\
\text { Yes }\end{array}$ & $\begin{array}{l}282(74.8) \\
95(25.2)\end{array}$ & $\begin{array}{l}28(9.9) \\
10(10.5)\end{array}$ & $\begin{array}{l}\text { Reference } \\
1.07 \text { (0.50 to } 2.29)\end{array}$ & 0.867 \\
\hline $\begin{array}{l}\text { Intense Emotional negligence } \\
\text { No } \\
\text { Yes }\end{array}$ & $\begin{array}{l}289(76.7) \\
88(23.3)\end{array}$ & $\begin{array}{l}26(9.0) \\
12(13.6)\end{array}$ & $\begin{array}{l}\text { Reference } \\
1.60(0.77 \text { to } 3.32)\end{array}$ & 0.206 \\
\hline $\begin{array}{l}\text { Intense Sexual Abuse } \\
\text { No } \\
\text { Yes }\end{array}$ & $\begin{array}{l}300(79.6) \\
77(20.4)\end{array}$ & $\begin{array}{l}31(10.3) \\
7(9.1)\end{array}$ & $\begin{array}{l}\text { Reference } \\
0.87(0.37 \text { to } 2.05)\end{array}$ & 0.747 \\
\hline $\begin{array}{l}\text { Intense Physical abuse } \\
\text { No } \\
\text { Yes }\end{array}$ & $\begin{array}{l}294(78.0) \\
83(22.0)\end{array}$ & $\begin{array}{l}24(8.2) \\
14(16.9)\end{array}$ & $\begin{array}{l}\text { Reference } \\
2.28 \text { ( } 1.12 \text { to } 4.64)\end{array}$ & 0.020 \\
\hline $\begin{array}{l}\text { Intense Emotional Abuse } \\
\text { No } \\
\text { Yes }\end{array}$ & $\begin{array}{l}302(80.1) \\
75(19.9)\end{array}$ & $\begin{array}{l}28(9.3) \\
\text { I. }(13.3)\end{array}$ & $\begin{array}{l}\text { Reference } \\
\text { I.5। ( } 0.70 \text { to } 3.26)\end{array}$ & 0.296 \\
\hline
\end{tabular}

Notes: 'Major Depressive Disorder. *Chi-square test.

Based on the criteria defined by the MINI, $38.0 \%$ of the participants were considered at suicide risk; being $26.9 \%$ with mild risk, $7.2 \%$ with moderate risk and $4 \%$ with a high risk of suicide. As for substance use, 25.6\%, $25.1 \%, 25.9 \%$ and $5.3 \%$ of the interviewees were abusers or dependent on alcohol, tobacco, hypnotics and other drugs, respectively (Table 3).

The observed cumulative incidence of SA was $10.1 \%$. In the bivariate analysis, individuals with up to 8 years of schooling showed a higher SA incidence than those with higher education levels $(\mathrm{p}=0.035)$ (Table 1). Experiencing intense physical abuse during childhood was associated with an increase in SA incidence among depressed adults $(\mathrm{p}=0.020)$ (Table 2). Participants who were at risk of suicide upon joining the study had a 4 times higher SA incidence when compared to those who were not at risk of suicide $(\mathrm{p}<0.001)$ (Table 3$)$.
In the multivariable analysis, participants considered at risk of suicide presented an odds of attempting suicide 3.39 times higher than those not at risk (95\% CI 1.56 to 7.37). Participants who experienced intense childhood physical abuse had an odds of SA of 2.77 times higher compared to those who did not report intense abuse $(95 \%$ CI 1.31 to 5.84). Participants with up to 8 years of schooling had an odds of SA 2.35 times higher when compared to individuals with higher schooling (95\% CI 1.15 to 4.80). Participants up to 29 years of age had an odds of attempting suicide 2.23 times higher when compared to older individuals (95\% CI 1.13 to 4.64) (Table 4).

\section{Discussion}

This study sought to identify the cumulative incidence of SA and assess a wide range of potential risk factors in MDD diagnosed participants within 3 years. A $10.1 \%$ SA 
Table 3 Mental Health Characteristics of Participants Diagnosed with MDD' and Their Association with Attempted Suicide Incidence

\begin{tabular}{|c|c|c|c|c|}
\hline Variables & $\begin{array}{l}\text { n (\%) } \\
377\end{array}$ & $\begin{array}{l}\text { Suicide Attempt } \\
\text { Incidence n (\%) }\end{array}$ & Odds Ratio $(95 \% \mathrm{Cl})$ & p - value** \\
\hline $\begin{array}{l}\text { Risk of suicide } \\
\text { No } \\
\text { Yes }\end{array}$ & $\begin{array}{l}233(6 \mid .8) \\
144(38.2)\end{array}$ & $\begin{array}{l}\text { II (4.7) } \\
27(18.8)\end{array}$ & $\begin{array}{l}\text { Reference } \\
4.66 \text { ( } 2.23 \text { to } 9.72)\end{array}$ & $<0.001$ \\
\hline $\begin{array}{l}\text { Any kind of anxiety disorder } \\
\text { No } \\
\text { Yes }\end{array}$ & $\begin{array}{l}145(38.5) \\
232(6 \mid .5)\end{array}$ & $\begin{array}{l}15(10.3) \\
23(9.9)\end{array}$ & $\begin{array}{l}\text { Reference } \\
0.95(0.48 \text { to } 1.90)\end{array}$ & 0.892 \\
\hline $\begin{array}{l}\text { Obsessive compulsive disorder } \\
\text { No } \\
\text { Yes }\end{array}$ & $\begin{array}{l}288(76.4) \\
89(23.6)\end{array}$ & $\begin{array}{l}29(10.1) \\
9(10.1)\end{array}$ & $\begin{array}{l}\text { Reference } \\
I .00(0.46 \text { to } 2.21)\end{array}$ & 0.991 \\
\hline $\begin{array}{l}\text { Post-traumatic stress disorder } \\
\text { No } \\
\text { Yes }\end{array}$ & $\begin{array}{l}356(94.4) \\
21(5.6)\end{array}$ & $\begin{array}{l}36(10.1) \\
2(9.5)\end{array}$ & $\begin{array}{l}\text { Reference } \\
0.94(0.21 \text { to } 4.18)\end{array}$ & 0.931 \\
\hline $\begin{array}{l}\text { Alcohol abuse/dependence* } \\
\text { No } \\
\text { Yes }\end{array}$ & $\begin{array}{l}267(74.4) \\
92(25.6)\end{array}$ & $\begin{array}{l}26(9.7) \\
10(10.9)\end{array}$ & $\begin{array}{l}\text { Reference } \\
\text { I.I3 (0.52 to } 2.44)\end{array}$ & 0.755 \\
\hline $\begin{array}{l}\text { Tobacco abuse/dependence* } \\
\text { No } \\
\text { Yes }\end{array}$ & $\begin{array}{l}269(74.9) \\
90(25.1)\end{array}$ & $\begin{array}{l}23(8.6) \\
13(14.4)\end{array}$ & $\begin{array}{l}\text { Reference } \\
\text { I.8I }(0.87 \text { to } 3.74)\end{array}$ & 0.107 \\
\hline $\begin{array}{l}\text { Hypnotic abuse/dependences* } \\
\text { No } \\
\text { Yes }\end{array}$ & $\begin{array}{l}266(74.1) \\
93(25.9)\end{array}$ & $\begin{array}{l}23(8.6) \\
13(14.0)\end{array}$ & $\begin{array}{l}\text { Reference } \\
\text { I.72 (0.83 to } 3.55)\end{array}$ & 0.141 \\
\hline $\begin{array}{l}\text { Other drugs abuse/dependence* } \\
\text { No } \\
\text { Yes }\end{array}$ & $\begin{array}{l}340(94.7) \\
19(5.3)\end{array}$ & $\begin{array}{l}34(10.0) \\
2(10.5)\end{array}$ & $\begin{array}{l}\text { Reference } \\
1.06(0.24 \text { to } 4.78)\end{array}$ & 0.941 \\
\hline $\begin{array}{l}\text { Schizoid Personality Disorder* } \\
\text { No } \\
\text { Yes }\end{array}$ & $\begin{array}{l}278(83.5) \\
55(16.5)\end{array}$ & $\begin{array}{l}23(8.3) \\
8(14.5)\end{array}$ & $\begin{array}{l}\text { Reference } \\
\text { I.89 (0.80 to } 4.47)\end{array}$ & 0.144 \\
\hline $\begin{array}{l}\text { Avoidant Personality Disorder* } \\
\text { No } \\
\text { Yes }\end{array}$ & $\begin{array}{l}264(79.3) \\
69(20.7)\end{array}$ & $\begin{array}{l}22(8.3) \\
9(13.0)\end{array}$ & $\begin{array}{l}\text { Reference } \\
\text { I.65 ( } 0.72 \text { to } 3.77)\end{array}$ & 0.231 \\
\hline $\begin{array}{l}\text { Dependent Personality Disorder* } \\
\text { No } \\
\text { Yes }\end{array}$ & $\begin{array}{l}264(79.3) \\
69(20.7)\end{array}$ & $\begin{array}{l}25(9.5) \\
6(8.7)\end{array}$ & $\begin{array}{l}\text { Reference } \\
0.91 \text { ( } 0.36 \text { to } 2.32)\end{array}$ & 0.844 \\
\hline $\begin{array}{l}\text { Histrionic Personality Disorder* } \\
\text { No } \\
\text { Yes }\end{array}$ & $\begin{array}{l}268(80.5) \\
65(19.5)\end{array}$ & $\begin{array}{l}26(9.7) \\
5(7.7)\end{array}$ & $\begin{array}{l}\text { Reference } \\
0.78(0.29 \text { to } 2.10)\end{array}$ & 0.617 \\
\hline $\begin{array}{l}\text { Narcissist Personality Disorder* } \\
\text { No } \\
\text { Yes }\end{array}$ & $\begin{array}{l}283(85.0) \\
50(15.0)\end{array}$ & $\begin{array}{l}26(9.2) \\
5(10.0)\end{array}$ & $\begin{array}{l}\text { Reference } \\
1.10 \text { (0.40 to } 3.01)\end{array}$ & 0.855 \\
\hline $\begin{array}{l}\text { Anti-social Personality disorder* } \\
\text { No } \\
\text { Yes }\end{array}$ & $\begin{array}{l}288(86.5) \\
45(13.5)\end{array}$ & $\begin{array}{l}28(9.7) \\
3(6.7)\end{array}$ & $\begin{array}{l}\text { Reference } \\
0.66(0.19 \text { to } 2.28)\end{array}$ & 0.512 \\
\hline
\end{tabular}

(Continued) 
Table 3 (Continued).

\begin{tabular}{|c|c|c|c|c|}
\hline Variables & $\begin{array}{l}\text { n (\%) } \\
377\end{array}$ & $\begin{array}{l}\text { Suicide Attempt } \\
\text { Incidence n (\%) }\end{array}$ & Odds Ratio $(95 \% \mathrm{Cl})$ & p - value** \\
\hline $\begin{array}{l}\text { Compulsive Personality Disorder* } \\
\text { No } \\
\text { Yes }\end{array}$ & $\begin{array}{l}264(80.8) \\
64(19.2)\end{array}$ & $\begin{array}{l}23(8.6) \\
8(12.5)\end{array}$ & $\begin{array}{l}\text { Reference } \\
\text { I.53 (0.65 to } 3.60)\end{array}$ & 0.328 \\
\hline $\begin{array}{l}\text { Schizotypal Personality Disorder* } \\
\text { No } \\
\text { Yes }\end{array}$ & $\begin{array}{l}291(87.4) \\
42(12.6)\end{array}$ & $\begin{array}{l}27(9.3) \\
4(9.5)\end{array}$ & $\begin{array}{l}\text { Reference } \\
1.03(0.34 \text { to } 3.10)\end{array}$ & 0.959 \\
\hline $\begin{array}{l}\text { Borderline Personality Disorder* } \\
\text { No } \\
\text { Yes }\end{array}$ & $\begin{array}{l}291(82.6) \\
56(17.4)\end{array}$ & $\begin{array}{l}22(8.0) \\
9(15.5)\end{array}$ & $\begin{array}{l}\text { Reference } \\
2.11 \text { ( } 0.92 \text { to } 4.86)\end{array}$ & 0.073 \\
\hline $\begin{array}{l}\text { Paranoid Personality Disorder* } \\
\text { No } \\
\text { Yes }\end{array}$ & $\begin{array}{l}29 \mid(83.2) \\
56(16.8)\end{array}$ & $\begin{array}{l}24(8.7) \\
7(12.5)\end{array}$ & $\begin{array}{l}\text { Reference } \\
\text { I.5I (0.62 to } 3.69)\end{array}$ & 0.368 \\
\hline $\begin{array}{l}\text { Any mental health treatment (psychological } \\
\text { or psychiatric) between the evaluations } \\
\text { No } \\
\text { Yes }\end{array}$ & $\begin{array}{l}23(6.1) \\
354(93.9)\end{array}$ & $\begin{array}{l}2(8.7) \\
36(10.2)\end{array}$ & $\begin{array}{l}\text { Reference } \\
\text { I.19(0.27 to } 5.28)\end{array}$ & 0.820 \\
\hline $\begin{array}{l}\text { How long did the mental health treatment } \\
\text { last? } \\
\text { No less than a month } \\
\text { One to six months } \\
\text { Seven to twelve months } \\
\text { Thirteen or more months }\end{array}$ & $\begin{array}{l}302(80.1) \\
42(I 1.1) \\
11(2.9) \\
22(5.8)\end{array}$ & $\begin{array}{l}33(10.9) \\
2(4.8) \\
1(9.1) \\
2(9.1)\end{array}$ & $\begin{array}{l}\text { I.23 (0.27 to } 5.49) \\
0.50(0.07 \text { to } 3.82) \\
\text { I.00 (0.08 to } 12.40) \\
\text { Reference }\end{array}$ & 0.506 \\
\hline
\end{tabular}

Notes: 'Major Depressive Disorder. *Variables with missing values. **Chi-square test.

incidence was observed in this sample. It was independently associated with being less than 30 years old, having less than 9 years of schooling, reporting intense physical abuse during childhood and being at risk of suicide at baseline.

The findings of our study must be interpreted considering a few limitations. First, our sample was not population based, with a convenience sample, which can limit the generalization of our findings. People fulfilling diagnostic criteria for MDD in a more severe episode or with higher disabilities might be less likely to look for treatment even with easy access and free of charges. Second, the relatively low statistical power may have prevented us from identifying other important risk factors that present a lower magnitude of effect. Furthermore, analyses performed with a modest sample may portrait associations with overestimated effect sizes and wide confidence intervals. These two limitations have to be considered.

We also had a follow-up loss of $18.8 \%$, which can be considered acceptable for a reassessment made 3 years later in a clinical sample. It is possible that the lost group might present more potential risk factors for unhealthy outcomes. Although it is important to highlight that just differences in sex and mother's history of SA were observed between the lost and reevaluated group. No death by suicide was observed after 3 years, even in the lost participants' group. Even though the sample was not population based, it is important to reiterate that the participants joined the study through referrals from primary health services and municipal healthcare services or through spontaneous interest, therefore including mostly the population who seeks the public healthcare system. The study involved only one follow-up round 3 years after baseline, presenting a large gap between first and second assessments. Therefore, immediate factors close to the moment of the SA could not be investigated.

Despite its limitations, our research presents an important contribution to the current literature about SA in subjects with MDD. Given we used a prospective study design, we measured the exposures previously to the outcome $_{\text {occurrence. }}{ }^{4}$ Moreover, we included a large 
Table 4 Logistic Regression Results for the Incidence of Attempted Suicide in Participants Diagnosed with MDD ${ }^{\prime}$

\begin{tabular}{|c|c|c|c|}
\hline Variables & Odds Ratio & $\mathrm{Cl}^{2}(95 \%)$ & p - value** \\
\hline Sex & & & 0.148 \\
\hline Female & 2.47 & 0.73 to 8.37 & \\
\hline Male & Reference & & \\
\hline Age & & & 0.022 \\
\hline Up to 29 years & 2.23 & 1.13 to 4.64 & \\
\hline 30 years or over & Reference & & \\
\hline Schooling (years) & & & 0.019 \\
\hline $0-8$ & 2.35 & I.I5 to 4.80 & \\
\hline $9+$ & Reference & & \\
\hline Occupation & & & 0.400 \\
\hline None & 1.36 & 0.66 to 2.81 & \\
\hline Works or studies & Reference & & \\
\hline Mother ever attempted suicide & & & 0.290 \\
\hline Never attempted/Does not know & Reference & & \\
\hline Has attempted & $\mathrm{I} .8 \mathrm{I}$ & 0.60 to 5.44 & \\
\hline Intense Physical Abuse & & & 0.007 \\
\hline No & Reference & & \\
\hline Yes & 2.77 & 1.31 to 5.84 & \\
\hline Schizoid Personality Disorder & & & 0.883 \\
\hline No & Reference & & \\
\hline Yes & 0.93 & 0.33 to 2.59 & \\
\hline Borderline Personality Disorder & & & 0.627 \\
\hline No & Reference & & \\
\hline Yes & 1.26 & 0.50 to 3.18 & \\
\hline Tobacco abuse/dependence & & & 0.375 \\
\hline No & Reference & & \\
\hline Yes & 1.43 & 0.65 to 3.13 & \\
\hline Hypnotics abuse/dependence & & & 0.141 \\
\hline No & Reference & & \\
\hline Yes & 1.78 & 0.83 to 3.86 & \\
\hline Risk of suicide & & & 0.002 \\
\hline No & Reference & & \\
\hline Yes & 3.39 & I. to 7.37 & \\
\hline
\end{tabular}

Notes: 'Major Depressive Disorder. ${ }^{2}$ Confidence Interval. **Logistic regression analyses.

selection of potential risk factors, including some so far unexplored in the literature. As far as we know, this is the first prospective study to assess SA predictors on depressed Latin American individuals.

In our sample, the SA incidence (10.1\%) along the life course differs from the findings of Bolton et al, which shows an incidence of $1.2 \%$ in a 3 -year follow-up. ${ }^{7}$ It is possible that the lower percentage is explained by the fact that the second study used a population-based MDD diagnosed population. When comparing with studies that assessed SA only during the follow-up, the cohort evaluated by Eikelenboom et al, composed of depressed individuals from primary healthcare units and from the community also showed a SA incidence lower than ours (3.4\% with a follow-up period of 6 years). ${ }^{14}$ Results like ours were reported by other authors that assessed follow-up incidence such as Riihimaki et al and Sokero et al, who found cumulative incidences of $10.4 \%$ (follow-up period of 5 years) and $8 \%$ (follow-up of 18 months), respectively. ${ }^{10,12}$ Even higher incidences were reported in the studies of Holma et al and Chan et al which showed 
rates of 14.5\% (5-year follow-up) and 18.2\% (1-year followup), respectively. ${ }^{8,9}$ Though these studies were carried out using participants clinically diagnosed with MDD, they did not exclude the individuals with prior SA history, having evaluated the SA incidence during the follow-up and not throughout the life course. Therefore, it is possible to infer that there was a higher incidence risk in those samples, taking into consideration the previous SA as the main predictor of a future attempt. ${ }^{12}$ Bearing this in mind, we can consider that the incidence in our sample was high. Another important point to be considered is that our study is composed exclusively of MDD patients initially without a history of SA; therefore, all SA observed is characterized by the first and single attempt. People with multiple SA represent a separate, more severe dimension of suicidal behavior than one SA. ${ }^{25,26}$ Few studies explore these differences suggesting that those with greater psychological and functional impairment may be more likely to make more than one attempt. ${ }^{2,27}$

Lower age and schooling were associated with higher odds of SA in our study. These findings are compatible with the literature. ${ }^{7,9,14,28-30}$ Regarding age, Bolton et al identified that subjects with 45 years of age or over were $60 \%$ less likely to attempt suicide along the lifetime than those with ages ranging from 18 to 29 years. ${ }^{7}$ Holma et al and Eikelenboom et al equally showed that among depressed individuals, young ones are more prone to attempting suicide. $^{9,14}$ Lower schooling was also reported by Eikelenboom et al as a risk factor for SA in MDD diagnosed individuals. ${ }^{14}$ The association between low schooling and SA was also shown in a study using a psychiatric sample composed of individuals with a borderline personality disorder. ${ }^{28}$ Schooling is a modifiable social vulnerability predictor of MDD and might be related to the information process biases common at this disorder affecting the decision-making process in suicidal behaviors. ${ }^{29,30}$ Developing countries should consider include in their treatment program strategies that include educational improvement as complementary interventions. Beyond social and behavioral activation promoted by educational activities, it might help this patient to increase cognitive flexibility.

Childhood trauma can play an important role in suicidal behavior among young adults, considering that it is associated with early psychiatric disorder manifestation ${ }^{31}$ and that its cognitive effects interact with cortical prefrontal systems still not fully developed, increasing the odds of impulsive behavior. ${ }^{32}$ We found, in our sample, intense physical abuse during childhood to be a predictor of SA. These findings corroborate the data obtained in the study by Yildirim et al, which indicated physical abuse to increase the chance of attempted suicide by $63 \%$ in individuals with MDD. ${ }^{33}$ Meta-analytical data identified childhood physical abuse as the most contributing trauma to SA, increasing its chance of occurrence by more than 4 times. ${ }^{34}$ When evaluating different samples from ours, it has been found, in a study assessing the general population, that childhood physical abuse was a suicidal ideation predictor along lifetime. ${ }^{35}$ Physical abuse was also recognized as one of the risk factors for the transition from ideation to $\mathrm{SA}^{36}$ regardless of the existence of a suicide plan. ${ }^{37}$ This type of trauma might influence particularly suicidal behavior in MDD patients.

The same explanatory understanding of the relationship between physical abuse and attempted suicide may be valid for an eventual influence on the history of sexual abuse and the same outcome. Sexual abuse is associated with SA in other studies $^{33,38}$ and clearly is a highly stressful event. Sexual and physical abuses are more strongly associated with SA than other types of childhood abuse. ${ }^{39}$ However, it is a type of trauma with a low occurrence probably requiring a large sample size to make it possible to observe any statistical difference. Other studies with MDD patients did not find any specific type of trauma associated with SA. ${ }^{40}$ More research is needed to better understand the role of each type of trauma in the suicide model. ${ }^{2}$

Suicidal ideation beginning at an early age and the existence of previous and/or present suicidal plans are the main risk factors for the first SA. ${ }^{37,41}$ We found an association between baseline suicide risk and SA during the follow-up period. This data is aligned with the current literature, Ten Have et al found that among individuals who had suicidal ideation, there was a $26.8 \%$ probability of a SA. ${ }^{42}$ Chan et al showed in a cohort of participants diagnosed with depressive disorders that all of those who attempted suicide had shown previous suicidal ideation. ${ }^{8}$ As such, it is possible to comprehend the existence of a continuum where SA risk increases in the presence of suicidal ideation and increases even further in the presence of a suicidal plan. ${ }^{43}$ These signs have to be taken into account when handling depressed patients, as indicators of SA risks.

\section{Conclusion}

Our results highlight that young individuals up to 29 years of age, with low schooling, who experienced physical abuse during childhood and who were at suicide risk (plans and ideation), have higher odds of attempting suicide in 
a sample of individuals with MDD within 3 years. Mental health professionals must increase the efforts to suicide prevention in MDD patients with these characteristics as well as clinical interventions should be addressed to it.

\section{Funding}

This work was supported by Brazilian research grant from CNPq.

\section{Disclosure}

The authors report no conflicts of interest for this work.

\section{References}

1. World Health Organization. Suicide in the world: global health estimates; 2019. Available from: https://apps.who.int/iris/bitstream/ handle/10665/326948/WHO-MSD-MER-19.3-eng.pdf? sequence= 1\&isAllowed=y. Accessed Aug 6, 2020.

2. Turecki G, Brent DA, Gunnell D, et al. Suicide and suicide risk. Nat Rev Dis Primers. 2019;5(1):1-22.

3. Chachamovich E, Stefanello Mullins N, Bigdeli TB, et al. GWAS of suicide attempt in psychiatric disorders and association with major depression polygenic risk scores. Am J Psychiatry. 2019;176 (8):651-660.

4. Ribeiro JD, Huang X, Fox KR, Franklin JC. Depression and hopelessness as risk factors for suicide ideation, attempts and death: meta-analysis of longitudinal studies. Br J Psychiatry. 2018;212 (5):279-286. doi:10.1192/bjp.2018.27

5. Dong M, Zeng LN, Lu L, et al. Prevalence of suicide attempt in individuals with major depressive disorder: a meta-analysis of observational surveys. Psychol Med. 2019;49(10):1691-1704. doi: $10.1017 /$ S0033291718002301

6. World Health Organization. Depression: World Health Organization depression fact sheet updated january; 2020. Avaliable from: https:// www.who.int/news-room/fact-sheets/detail/depression. Accessed Aug 6, 2020.

7. Bolton JM, Pagura J, Enns MW, Grant B, Sareen J. A population-based longitudinal study of risk factors for suicide attempts in major depressive disorder. J Psychiatr Res. 2010;44 (13):817-826. doi:10.1016/j.jpsychires.2010.01.003

8. Chan LF, Shamsul AS, Maniam T. Are predictors of future suicide attempts and the transition from suicidal ideation to suicide attempts shared or distinct: a 12-month prospective study among patients with depressive disorders. Psychiatry Res. 2014;220(3):867-873. doi:10.1016/j.psychres.2014.08.055

9. Holma KM, Melartin TK, Haukka J, Holma IAK, Sokero TP, Isometisa ET. Incidence and predictors of suicide attempts in DSM-IV major depressive disorder: a five-year prospective study. Am J Psychiatry. 2010;167(7):801-808. doi:10.1176/appi.ajp.2010.09050627

10. Riihimaki K, Vuorilehto M, Merlatin T, Haukka J, Isometsa E. Incidence and predictors of suicide attempts among primary-care patients with depressive disorders: a 5-year prospective study. Psychol Med. 2014;44(2):291-302. doi:10.1017/S0033291713000706

11. Ruengorn C, Sanichwankul K, Niwatananum W, Mahatnirunkun S, Pumpaisalchai W, Patumanond J. Factors related to suicide attempts among individuals with major depressive disorder. Int $J$ Gen Med. 2012;5:323-330.

12. Sokero TP, Melartin TK, Rytsala H, Leskela U, Lesteka-Mielonen PS, Isometsa ET. Prospective study of risk factors for attempted suicide among patients with DSM-IV major depressive disorder. $\mathrm{Br}$ J Psychiatry. 2005;186(4):314-318. doi:10.1192/bjp.186.4.314
13. Souza LDM, Molina ML, Silva RA, Jansen K. History of childhood trauma as risk factors to suicide risk in major depression. Psychiatry Res. 2016;246:612-616. doi:10.1016/j.psychres.2016.11.002

14. Eikelenboom M, Beekman ATF, Penninx BWJH, Smit JH. A 6-year longitudinal study of predictors for suicide attempts in major depressive disorder. Psychol Med. 2019;49(6):921. doi:10.1017/ S0033291718001423

15. Hawton K, Comabella CC, Haw C, Saunders K. Risk factors for suicide in individuals with depression: a systematic review. $J$ Affect Disord. 2013;147(1-3):17-28. doi:10.1016/j.jad.2013.01.004

16. Dos Santos ÉN, Molina ML, Mondin T, et al. Long-term effectiveness of two models of brief psychotherapy for depression: a three-year follow-up randomized clinical trial. Psychiatry Res. 2020;286:112804.

17. Amorim P. Mini international neuropsychiatric interview (MINI): validação de entrevista breve para diagnóstico de transtornos mentais. Rev Bras Psiquiatr. 2000;22(3):106-115. doi:10.1590/S151644462000000300003

18. Henrique IFS, De Micheli D, Lacerda RB, Lacerda LA, Formigoni MLODS. Validação da versão brasileira do teste de triagem do envolvimento com álcool, cigarro e outras substâncias (ASSIST). Rev Assoc Med Bras. 2004;50(2):199-206. doi:10.1590/ S0104-42302004000200039

19. Grassi-Oliveira R, Cogo-Moreira H, Salum GA, et al. Childhood trauma questionnaire (CTQ) in Brazilian samples of different age groups: findings from confirmatory factor analysis. PLoS One. 2014;9(1):87-118. doi:10.1371/journal.pone.0087118

20. Craig J. Millon clinical multiaxial inventory - III. In: Strack S, editor. Essentials of Millon Inventories Assessment. New Jersey: John Wiley \& Sons; 2008.

21. Craig RJ. New Directions in Interpreting the Millon Clinical Multiaxial Inventory-III (MCMI-III). Ed. John Wiley \& Sons; 2005.

22. Associação Brasileira de Empresas de Pesquisa. Critério de classificação econômica Brasil; 2008. Avaliable from: http://www. abep.org/criterio-brasil. Accessed Jun 15, 2012.

23. Lee KI, Koval JJ. Determination of the best significance level in forward stepwise logistic regression. Commun Stat Simul Comput. 1997;26(2):559-575. doi:10.1080/03610919708813397

24. Carson SS. Outcomes research: methods and implications. Semin Respir Crit Care Med. 2010;31(1):3-12. doi:10.1055/s-0029-1246281

25. Goldston DB, Erkanli A, Daniel SS, Heilbron N, Weller BE, Doyle O. Developmental trajectories of suicidal thoughts and behaviors from adolescence through adulthood. $J$ Am Acad Child Adolesc Psychiatry. 2016;55(5):400-407. doi:10.1016/j.jaac.2016.02.010

26. Defayette AB, Leah AM, Whitmyre ED, Williams CA, EspositoSmythers C. Characteristics of a first suicide attempt that distinguish between adolescents who make single versus multiple attempts. Arch Suicide Res. 2019;1-15.

27. Michaelis BH, Goldberg JF, Singer TM, Garno JL, Ernst CL, Davis GP. Characteristics of first suicide attempts in single versus multiple suicide attempters with bipolar disorder. Compr Psychiatry. 2003;44(1):15-20. doi:10.1053/comp.2003.50004

28. Soloff PH, Chiappetta L. Prospective predictors of suicidal behavior in borderline personality disorder at 6-year follow-up. Am J Psychiatry. 2012;169(5):484-490. doi:10.1176/appi.ajp.2011.11091378

29. Braithwaite EC, O'Connor RM, Degli-Esposti M, Luke N, Bowes L. Modifiable predictors of depression following childhood maltreatment: a systematic review and meta-analysis. Transl Psychiatry. 2017;7(7):e1162. doi:10.1038/tp.2017.140

30. Beck AT, Bredemeier K, Unified A. Model of depression: integrating clinical, cognitive, biological, and evolutionary perspectives. Clin Psychol Sci. 2016;4(4):596-619. doi:10.1177/2167702616628523

31. Scott KM, McLaughlin KA, Smith DAR, Ellis PM. Childhood maltreatment and DSM-IV adult mental disorders: comparison of prospective and retrospective findings. $B r J$ Psychiatry. 2012;200 (6):469-475. doi:10.1192/bjp.bp.111.103267 
32. Lee FS, Heimer H, Giedd JN, et al. Adolescent mental healthopportunity and obligation. Science. 2014;346(6209):547-549. doi:10.1126/science.1260497

33. Yildirim F, Küçükgöncü S, Beştepe EE, Yildirim MS. The relationship of childhood abuse and neglect with suicide attempts in an adult unipolar depression sample. Noro Psikiyatr Ars. 2014;51(2):133-140. doi:10.4274/npa.y6802

34. Zatti C, Rosa V, Barros A, et al. Childhood trauma and suicide attempt: a meta-analysis of longitudinal studies from the last decade. Psychiatry Res. 2017;256:353-358.

35. Fuller-Thomson E, Baker TM, Brennenstuhl S. Evidence supporting an independent association between childhood physical abuse and lifetime suicidal ideation. Suicide Life Threat Behav. 2012;42 (3):279-291. doi:10.1111/j.1943-278X.2012.00089.x

36. Yang L, Zhang Z, Sun L, Wu H, Sun Y. Risk and risk factors of suicide attempt after first onset of suicide ideation: findings from medical students in grades 1 and 2. Wei Sheng Yan Jiu. 2014;43 (1):47-53.

37. Nock MK, Borges G, Bromet EJ, et al. Cross-national prevalence and risk factors for suicidal ideation, plans and attempts. Br J Psychiatry. 2008;192(2):98-105. doi:10.1192/bjp.bp.107.040113

38. Baek JH, Kim K, Hong JP, et al. Binge eating, trauma, and suicide attempt in community adults with major depressive disorder. PLoS One. 2018;13(6):e0198192. doi:10.1371/journal.pone.0198192
39. Joiner TE JR, Sachs-Ericsson NJ, Wingate LR, Brown JS, Anestis MD, Selby EA. Childhood physical and sexual abuse and lifetime number of suicide attempts: a persistent and theoretically important relationship. Behav Res Ther. 2007;45(3):539-547. doi:10.1016/j.brat.2006.04.007

40. Goldberg X, Serra-Blasco M, Vicent-Gil M, et al. Childhood maltreatment and risk for suicide attempts in major depression: a sex-specific approach. Eur J Psychotraumatol. 2019;10(1):1603557. doi:10.1080/20008198.2019.1603557

41. Nock MK, Green GJ, Hwang I, et al. Prevalence, correlates, and treatment of lifetime suicidal behavior among adolescents: results from the national comorbidity survey replication adolescent supplement. JAMA Psychiatry. 2013;70(3):300-310. doi:10.1001/ 2013.jamapsychiatry.55

42. Ten Have M, Van Dorsselaer S, De Graaf R. Prevalence and risk factors for first onset of suicidal behaviors in the Netherlands mental health survey and incidence study-2. J Affect Disord. 2013;147(1-3):205-211. doi:10.1016/j.jad.2012.11.005

43. Borges G, Nock MK, Abad JMH, et al. Twelve month prevalence of and risk factors for suicide attempts in the WHO World mental health surveys. J Clin Psychiatry. 2010;71(12):1617-1628.
Psychology Research and Behavior Management

\section{Publish your work in this journal}

Psychology Research and Behavior Management is an international, peer-reviewed, open access journal focusing on the science of psychology and its application in behavior management to develop improved outcomes in the clinical, educational, sports and business arenas. Specific topics covered in the journal include: Neuroscience, memory and decision making; Behavior modification and management; Clinical applications; Business and sports performance management; Social and developmental studies; Animal studies. The manuscript management system is completely online and includes a very quick and fair peer-review system, which is all easy to use. Visit http://www. dovepress.com/testimonials.php to read real quotes from published authors. 